\title{
Bilabial Palatalisation in Zulu: A morphologically conditioned phenomenon $^{1}$
}

\author{
Andrew van der Spuy \\ Department of Linguistics, University of the Witwatersrand, Johannesburg, South Africa \\ E-mail: andrew.vanderspuy@wits.ac.za
}

\begin{abstract}
This article looks at the question of whether the palatalisation processes which occur in the Zulu locative, diminutive and passive are best regarded as morphologically conditioned or as phonologically conditioned. For each of these processes, arguments are presented to show that they are morphologically conditioned, and that proposed analyses of them as phonologically conditioned are incorrect. It is further argued that the rules which prevent VV sequences from arising are also morphologically conditioned. Formal morphologically conditioned analyses of each process are given.
\end{abstract}

Keywords: Zulu, morphology, palatalisation, phonologically conditioned, morphologically conditioned, rule ordering

\section{Introduction}

Phonological processes can be classified into two kinds: the phonologically conditioned, which take place wherever a particular set of phonological circumstances are met, and the morphologically (or lexically) conditioned, which take place only in certain specified morphological circumstances (see, for example, Bloomfield 1935:211ff; Chomsky and Halle 1968: e.g. 10-11; Aronoff 1976 (esp. ch. 4); Kiparsky 1982, 1985). This distinction has not always been made in descriptions of Zulu: Doke (1926) discusses "pre-palatalization" under the heading of "Phonetics in the Morphology", but in his later works $(1927,1973)$ he does not classify the processes and simply lists palatalisation as part of "the phonetical structure" of Zulu; Poulos and Msimang (1998:503ff) list all "sound changes" under the general heading "Aspects of Phonology". By "sound changes" they mean synchronic phonological processes, including Bilabial Palatalisation (see Poulos and Msimang 1998:518-519).

In several phonological frameworks, it is assumed that morphologically conditioned rules operate before phonologically conditioned ones. Examples of such frameworks are Lexical

\footnotetext{
${ }^{1}$ I would like to thank Sandra Linton for editing this article, and two anonymous reviewers for their constructive and encouraging comments and suggestions which have helped to improve the article considerably. All remaining errors and faults are, of course, my own.
} 
Phonology (Kiparsky 1982, 1985), Autosegmental Phonology (Goldsmith 1990), and Distributed Morphology (Halle and Marantz 1993).

One of the most complex phonological processes that takes place in Zulu is Bilabial Palatalisation. Henceforth, the term "Bilabial Palatalisation" will be used specifically to refer to this phenomenon as it occurs in Zulu. Bilabial Palatalisation is a process, or set of processes, that substitutes an (alveo)palatal consonant for a bilabial one, as shown in (1). Both the input and output forms are shown in phonological transcription as these are processes which substitute one phoneme for another. Phonological transcription is followed by the standard orthographical representation.

$$
\begin{aligned}
& / \mathrm{p}^{\mathrm{h}} / \rightarrow / \mathrm{S} /(\mathrm{ph} \rightarrow \mathrm{sh}) \\
& / \mathrm{p} / \rightarrow / \mathrm{t} f /(\mathrm{p} \rightarrow \mathrm{tsh}) \\
& / \mathrm{b} / \rightarrow / \mathrm{t} \mathrm{f} /(\mathrm{b} \rightarrow \mathrm{tsh}) \\
& / \mathrm{b}^{\mathrm{f}} / \rightarrow / \mathrm{d} z /(\mathrm{bh} \rightarrow \mathrm{j}) \\
& / \mathrm{mp} / \rightarrow / \mathrm{nt} f /(\mathrm{mp} \rightarrow \mathrm{ntsh}) \\
& / \mathrm{m} / \rightarrow / \mathrm{n} /(\mathrm{m} \rightarrow \mathrm{ny}) \\
& / \mathrm{mb}^{\mathrm{f}} / \rightarrow / \mathrm{ndz} /(\mathrm{mb} \rightarrow \mathrm{nj}) \\
& \text { (cf. Doke 1973:21, 75, 136, 233-234; Poulos and Msimang 1998:531-534) }
\end{aligned}
$$

These processes will be summarised in the formula $\mathrm{B} \rightarrow \mathrm{J}$ : "a bilabial consonant (cluster) is replaced by an (alveo)palatal consonant (cluster)". ${ }^{2}$ In the discussion that follows, standard orthography will be used as it is quite transparent and unambiguous.

Bilabial Palatalisation is productive in three circumstances: the diminutive forms of nouns, the locative forms of nouns, and the passive forms of verbs. There is also a non-productive remnant of the process in the class (cl.)14 nouns utshwala ('beer') $<* u$-bu-ala and utshani ('grass') $<* u$-buani (Doke 1973:59; Guthrie 1971:63 records a similar process in the closely-related Xhosa).

A question which has frequently been addressed in the literature is whether there is a phonological trigger for palatalisation, that is, whether it is a phonological process (or a set of phonological processes) or a morphologically conditioned one. Stahlke (1976) and Kotzé and Zerbian (2008) argue that the similar palatalisation processes found in the Sotho languages are phonological. Louw (1976) seeks to explain the process in terms of historical phonological change. Khumalo (1987) argues that palatalisation is generally phonological except that he considers one of its operations in the passive to be morphologically conditioned (see the discussion in section 8 of this paper). Herbert

\footnotetext{
2 The following symbols and abbreviations are used here:

agr: agreement

B: bilabial consonant (cluster)

-blb: non-bilabial

bk: back

C: consonant

cl. $n$ : (where $n$ is a numeral) class $n$

dim: diminutive

hi: high

$\mathrm{J}$ : (alveo)palatal consonant (cluster)

loc: locative

$\mathrm{N}$ : nasal consonant

nom: nominal

pass: passive

syl: syllabic

$\mathrm{V}$ : vowel

*VV: two vowels may not occur in sequence at surface level
} 
(1977, 1990) argues that palatalisation is morphologically conditioned. Malambe (2010:40) mentions a phonological trigger but states that she is discussing "palatalization in the passive", implying that she sees the process as morphologically conditioned. Ohala (1978) follows Herbert (1977) by analysing palatalisation as synchronically morphological but, like Louw (1976), he is largely concerned with providing a diachronic phonological motivation for the palatalisation processes. Canonici (1996) gives an analysis closely based on that of Khumalo (1987) but characterises the processes as "morpho-phonological" (1996:60) rather than phonological, although he does not explain his reasons for this.

Herbert's (1977:156) arguments for regarding Bilabial Palatalisation as morphologically conditioned are: first, the "phonetic non-naturalness of the synchronic alternations", second, the fact that they are "synchronically associated with particular grammatical categories", third, that there are "many exceptions and idiosyncrasies", and fourth that, in the passive, "labial consonants are palatalized even when they are no longer stem-final" (1977:157). He does not describe the processes in any formal terms (1977, 1990). In a later work (Herbert 1990), he presents psycholinguistic evidence to show that Bilabial Palatalisation is morphological rather than phonological.

This article will provide formal morphologically conditioned accounts of Bilabial Palatalisation in the three contexts where it occurs productively, together with sample derivations (sections 3-7). It will demonstrate that, on close examination, the so-called "phonological accounts" are actually morphologically driven (section 8).

\section{An overview of the constructions in which palatalisation occurs}

\subsection{The diminutive}

The basic facts of diminutive formation are as follows. The diminutive is formed by adding a suffix, realised as $-a n a$, to a noun. If the noun ends in $-a,-e$, or $-i$, then the final vowel of the noun is elided:

$$
\begin{aligned}
& \text { umfula 'river' } \rightarrow \text { umfula-ana } \rightarrow \text { umfulana } \\
& \text { isikole 'school' } \rightarrow \text { isikole-ana } \rightarrow \text { isikolana } \\
& \text { umakoti 'bride' } \rightarrow \text { umakoti-ana } \rightarrow \text { umakotana }
\end{aligned}
$$

If the noun ends in $-o$ or $-u$, then the final vowel is replaced by $-w$ :

$$
\begin{aligned}
& \text { isondo 'wheel' } \rightarrow \text { isondo-ana } \rightarrow \text { isondw-ana } \\
& u f u d u \text { 'tortoise' } \rightarrow \text { ufudu-ana } \rightarrow \text { ufudw-ana }
\end{aligned}
$$

If the noun ends in a bilabial consonant (cluster) followed by any vowel, then the bilabial consonant (cluster) and vowel are replaced by an (alveo)palatal consonant:

$$
\begin{aligned}
& \text { intamo 'neck' } \rightarrow \text { intamo-ana } \rightarrow \text { intany-ana } \\
& \text { ikopi 'cup' } \rightarrow \text { ikopi-ana } \rightarrow \text { ikotsh-ana } \\
& \text { intaba 'mountain' } \rightarrow \text { intaba-ana } \rightarrow \text { intatsh-ana }
\end{aligned}
$$




\subsection{The locative}

The basic facts of the locative are these. The locative form of a noun is marked by a prefix $e-$ ( $\sim-$ in cl.11). The prefix is attached to what Progovac (1993) calls the "bare form" of the noun, that is, the form without the initial vowel (or "augment") which is found in the citation form of every Zulu noun.

The locative is simultaneously marked by a suffix. ${ }^{3}$ If the noun ends in $-a$ or $-e$, the final vowel is replaced by a suffix which is realised as -eni:

$$
\begin{aligned}
& \text { intaba 'mountain' } \rightarrow \text { e-ntaba-eni } \rightarrow \text { entabeni } \\
& \text { isikole 'school' } \rightarrow \text { e-sikole-eni } \rightarrow \text { esikoleni }
\end{aligned}
$$

If the noun ends in $-i$, the final vowel is replaced by a suffix $-i n i$ :

$$
\text { umkhumbi 'ship' } \rightarrow \text { e-mkhumbi-ini } \rightarrow \text { emkhumbini }
$$

If the noun ends in $-o$, the final vowel becomes a glide and a suffix realised as - en $i$ is added:

$$
\text { umkhonto 'spear' } \rightarrow \text { e-mkhonto-eni } \rightarrow \text { emkhontweni }
$$

If the noun ends in $-u$, the final vowel becomes a glide and a suffix -ini is added:

$$
\text { izulu 'sky' } \rightarrow \text { e-zulu-ini } \rightarrow \text { ezulwini }
$$

If the noun ends in a bilabial consonant (cluster) followed by $-o$, the bilabial consonant (cluster) is replaced by a palatal and the final vowel is replaced by a suffix realised as -eni.

$$
\text { umthombo 'fountain' } \rightarrow \text { e-mthombo-eni } \rightarrow \text { emthonjeni }
$$

If the noun ends in a bilabial consonant (cluster) followed by $-u$, the bilabial consonant (cluster) is replaced by a palatal and the final vowel is replaced by a suffix -ini.

$$
\text { isigubhu 'calabash' } \rightarrow \text { e-sigubhu-ini } \rightarrow \text { esigujini }
$$

\subsection{The passive}

The Bilabial Palatalisation in the passive has been extensively described in the reference grammars. The rudimentary facts of Passive Palatalisation are as follows. The passive morpheme is $-w$ :

$$
\text { theng- } a \text { 'buy' theng-w-a 'be bought' }
$$

The passive morpheme brings about palatalisation in a preceding bilabial consonant:

$$
\text { lim-w-a 'be ploughed' } \rightarrow \text { liny-w-a }
$$

\footnotetext{
${ }^{3}$ There are a few nouns that do not take any suffix in the locative - see Doke (1973:235) and Poulos and Msimang (1998:407).
} 
The passive $-w$ need not be immediately adjacent to the palatalised consonant:

$$
\text { dubul-w-a 'be shot' } \rightarrow \text { dutshul-w-a }
$$

The passive morpheme has an allomorph $-i w$ which is used after roots of the form $\mathrm{C}$ or $\mathrm{VC}$ :

$$
\begin{aligned}
& k h-i w-a \text { 'be plucked' } \\
& a b-i w-a \text { 'be divided' }
\end{aligned}
$$

The $-i w$ allomorph is also used in the perfect form of verbs:

$$
\text { lim-iw-e 'have been ploughed' }
$$

This $-i w$ does not have any palatalising effect on a preceding consonant.

\section{Bilabial Palatalisation as a set of morphologically conditioned processes}

The diminutive suffix has been analysed either as - ana or as -yana, with the diminutive formed in one of the following two ways:
a. intaba 'mountain' + ana $\rightarrow$ intab-ana $\rightarrow$ intatsh-ana
b. intaba 'mountain' + yana $\rightarrow$ intab-yana $\rightarrow$ intatsh-yana $\rightarrow$ intatshana

(For a more detailed discussion of (16a), see section 4 of this paper; for a more detailed discussion of (16b), see section 8.)

On the first analysis, Diminutive Palatalisation is clearly morphological; if it were not, then all bilabial consonants would be palatalised before the vowel $a$. Hundreds of words confirm that this does not happen, e.g. all cl.2 nouns which begin with the prefix $a b a-$, as in aba-ntu ('people'). On the second analysis, Diminutive Palatalisation must also be morphological. There are other morphological circumstances where sequences like $m y$ or by arise but no palatalisation takes place. Examples are given in (17). By the process of Glide Formation (described in the Appendix), the underlying vowel $i$ becomes $y$ when followed by another vowel.

$$
\begin{aligned}
& \text { imi-ahluko 'differences' (cl.4) } \rightarrow \text { imy-ahluko } \rightarrow \text { im-ahluko not *iny-ahluko } \\
& \text { (cf. imi-lenze 'legs') } \\
& i \text {-be-i-elus- } a \text { 'he (cl.9) was herding' } \rightarrow i \text {-b-i-elus- } a \rightarrow i \text {-b-y-elus- } a \rightarrow i \text { - } b \text {-elus- } a \\
& \text { not } * i \text {-tsh-elus-a } \\
& \text { (cf. } i-b-i-s i z-a \text { 'he (cl.9) was helping') }
\end{aligned}
$$

(The $-a$ at the end of the verb stem is the semantically-empty default verbal morpheme, often called the "final vowel".)

Therefore, on either analysis of the diminutive suffix, Diminutive Palatalisation is morphologically conditioned.

Like Diminutive Palatalisation, Locative Palatalisation is also morphologically conditioned. It comes about when the locative suffix -ini is attached to a noun ending on a bilabial consonant 
followed by a back vowel. But there are other morphological environments where the sequence $\mathrm{BV}_{[+\mathrm{bk}]} \mathrm{V}_{[-\mathrm{bk}]}$ does not yield a palatal consonant. For example, there is no palatalisation in the noun class prefix $u m u$ - when it attaches to a stem beginning with a front vowel, or in the subject marker $b u$ - when it is prefixed to a verb stem beginning with a front vowel. In such circumstances, the vowel $u$ is assumed to become $w$ before a vowel-commencing stem by Glide Formation, then to dissimilate to $y$ by Labial Glide Dissimilation, then to delete by Y-Deletion. (See the Appendix for a description of these processes.)

$$
\begin{aligned}
& \text { umu-elusi 'herder' } \rightarrow \text { umw-elusi } \rightarrow \text { umy-elusi } \rightarrow \text { um-elusi not } * \text { uny-elusi } \\
& b u+\text { enele 'it }(\mathrm{cl} .14) \text { is enough' } \rightarrow \text { bw-enele } \rightarrow \text { by-enele } \rightarrow \text {-enele not } * \text { tsh-enele }
\end{aligned}
$$

Third, Passive Palatalisation is a morphologically conditioned rule. The passive is formed by adding $-w$ to a verb stem, thus:

$$
\text { lob-a 'write' } \rightarrow \text { lob-w- } a \text { 'be written' } \rightarrow \text { lotsh-w- } a
$$

When $a-w$ is derived by Glide Formation, no palatalisation takes place, as shown in (18) above.

As the palatalisation rules do not operate in all morphological circumstances where their phonological conditions are found, they must be morphologically conditioned.

\section{The diminutive}

The elision or gliding of the final vowel of the noun in the diminutive (described in section 2.1) can be accounted for by the independently motivated *VV Avoidance rules of Glide Formation,

\begin{tabular}{|c|c|c|c|c|}
\hline intaba & uphaphe & umkhumbi & intamo & isigubhu \\
\hline 'mountain' & 'feather' & 'ship' & 'neck' & 'calabash' \\
\hline intaba-ana & uphaphe-ana & umkhumbi-ana & intamo-ana & isigubhu-ana \\
\hline - & - & umkhumby-ana & intamw-ana & isigubhw-ana \\
\hline - & 一 & - & intamy-ana & - \\
\hline- & - & umkhumb-ana & intam-ana & isigubh-ana \\
\hline intab-ana & uphaph-ana & - & - & - \\
\hline intatsh-ana & uphash-ana & umkhunj-ana & intany-ana & isiguj-ana \\
\hline
\end{tabular}
Y-Deletion and Vowel Deletion (see Appendix). This is shown in the table in (20).

The morphologically conditioned rule of Diminutive Palatalisation operates as follows:

(21) Diminutive Palatalisation: a bilabial consonant is palatalised before the diminutive suffix - ana.

$$
\mathrm{B} \rightarrow \mathrm{J} / \ldots \text {-ana }[+\operatorname{dim}]
$$

If morphological rules precede phonological ones, then the *VV Avoidance rules of Glide Formation, Labial Glide Dissimilation, Y-Deletion and Vowel Deletion must be morphologically conditioned because they have to precede Diminutive Palatalisation. They cannot follow it, for two reasons. First, if the Diminutive Palatalisation rule has the form above, palatalisation would never take place because the bilabial consonant would always be separated from the suffix - ana by the final vowel of the noun stem. 


\begin{tabular}{ll}
$\begin{array}{ll}\text { uphaphe } \\
\text { 'feather' }\end{array}$ & $\begin{array}{l}\text { umkhumbi } \\
\text { 'ship' }\end{array}$ \\
\hline uphaphe-ana & umkhumbi-ana \\
- & - \\
- & umkhumby-ana \\
* & *umkhumb-ana \\
& -
\end{tabular}

Second, even if the Diminutive Palatalisation rule is modified, as in (23), so that palatalisation takes place before deletion of the final vowel of the noun, incorrect results are produced.

$$
\text { Diminutive Palatalisation \#2: } \mathrm{B} \rightarrow \mathrm{J} / \ldots \mathrm{V}-a n a[+\operatorname{dim}]
$$

In the diminutive of words like intamo ('neck'), $-w$ would not be elided after the palatal consonant because the trigger which causes it to dissimilate and subsequently elide, namely the bilabial consonant, would already have been changed to a non-bilabial.

\section{Affixation}

Diminutive Palatalisation \#2

Glide Formation

Labial Glide Dissimilation

Y-Deletion

Vowel Deletion

$\begin{array}{ll}\begin{array}{ll}\text { uphaphe } \\ \text { 'feather' }\end{array} & \begin{array}{l}\text { intamo } \\ \text { 'neck' }\end{array} \\ \text { uphaphe-na } & \text { intamo-ana } \\ \text { uphashe-ana } & \text { intanyo-ana } \\ - & \text { *intanyw-ana } \\ - & - \\ \text { - } & - \\ \text { uphash-ana } & -\end{array}$

The following tables provide sample derivations using the order of rules argued for above, and the Diminutive Palatalisation rule in (21). Table (25) shows nouns that do not undergo palatalisation, and table (26) shows nouns that do.

\begin{tabular}{|c|c|c|c|c|c|}
\hline & 'river' & 'fool' & 'water' & 'wheel' & 'deaf person' \\
\hline Affixation & umfula-ana & umphuhle-ana & amanzi-ana & isondo-ana & isithulu-ana \\
\hline Glide Formation & - & - & amanzy-ana & isondw + ana & isithulw-ana \\
\hline Labial Glide Dissimilation & - & - & - & - & - \\
\hline Y-Deletion & - & - & amanz-ana & - & - \\
\hline Vowel Deletion & umful-ana & umphuhl-ana & - & - & - \\
\hline Diminutive Palatalisation & - & - & - & - & - \\
\hline \multirow[t]{2}{*}{ (26) } & intaba & uphaphe & umkhumbi & intamo & isigubhu \\
\hline & 'mountain' & 'feather' & 'ship' & 'neck' & 'calabash' \\
\hline Affixation & intaba-ana & uphaphe-ana & umkhumbi-ana & intamo-ana & isigubhu-ana \\
\hline Glide Formation & - & - & umkhumby-ana & intamw-ana & isigubhw-ana \\
\hline Labial Glide Dissimilation & - & - & - & intany-ana & isigubhy-ana \\
\hline Y-Deletion & - & - & umkhumb-ana & intam-ana & isigubh-ana \\
\hline Vowel Deletion & intab-ana & uphaph-ana & - & - & - \\
\hline Diminutive Palatalisation & intatsh-ana & uphash-ana & umkhunj-ana & intany-ana & isiguj-ana \\
\hline
\end{tabular}




\section{The locative}

The facts of locative formation described in section 2.2 can be accounted for by assuming that the locative suffix is -ini (as assumed by Khumalo 1987:140, 145). The Vowel Lowering rule applies (see Appendix), followed by a rule of Locative Palatalisation.

(27) Locative Palatalisation: a sequence of bilabial consonant and back vowel is replaced by an (alveo)palatal consonant before the locative suffix.

$$
\mathrm{BV}_{[+\mathrm{bk}]} \rightarrow \mathrm{J} / \text { _ }_{-i n i} \sim-e n i[+\mathrm{loc}]
$$

Once these rules have applied, the other *VV Avoidance rules apply, namely Glide Formation, Y-Deletion and Vowel Deletion (see Appendix).

The table in (28) shows sample derivations of locative forms.

\begin{tabular}{lllll} 
(28) & $\begin{array}{l}\text { isondo } \\
\text { 'wheel' }\end{array}$ & $\begin{array}{l}\text { indaba } \\
\text { 'affair' }\end{array}$ & $\begin{array}{l}\text { ichibi } \\
\text { 'pool' }\end{array}$ & $\begin{array}{l}\text { izihlobo } \\
\text { 'relatives' }\end{array}$ \\
\hline Affixation & e-sondo-ini & e-ndaba-ini & e-chibi-ini & e-zihlobo-ini \\
Vowel Lowering & e-sondo-eni & e-ndaba-eni & - & e-zihlobo-eni \\
Locative Palatalisation & - & - & - & e-zihlotsh-eni \\
Glide Formation & e-sondw-eni & - & e-chiby-ini & - \\
Labial Glide Dissimilation & - & - & - & - \\
Y-Deletion & - & - & e-chib-ini & - \\
Vowel Deletion & - & e-ndab-eni & - & -
\end{tabular}

Locative Palatalisation has to precede Glide Formation or else the back vowel is lost, as shown in the following derivation.

izihlobo

'relatives'

\begin{tabular}{ll}
\hline Affixation & e-zihlobo-ini \\
Vowel Lowering & e-zihlobo-eni \\
Glide Formation & e-zihlobw-eni \\
Labial Glide Dissimilation & e-zihloby-eni \\
Y-Deletion & *e-zihlob-eni \\
Vowel Deletion & - \\
Locative Palatalisation & -
\end{tabular}

If the rules are applied in this order, then the locative of izihlobo is realised as *ezihlobeni instead of ezihlotsheni because the back vowel, which is part of the palatalisation process, is lost.

Vowel Lowering has to precede Locative Palatalisation or else incorrect forms would be produced, as shown in (30). 
If the rules are applied in this order, then the Vowel Lowering environment is lost, and the locative of izihlobo is realised as *ezihlotshini instead of ezihlotsheni.

Vowel Lowering is morphologically conditioned (i) because it precedes Locative Palatalisation which, as shown in section 3, is morphologically conditioned, and (ii) because it happens only in certain environments and not in others. For example, it does not happen when the hortative prefix $m a-$ is attached to a verb beginning with a high vowel. In this construction, the second vowel remains high and a glide is inserted between the vowels, thus ma + ibuye 'it (cl.9) should return' $\rightarrow$ mayibuye 'may it return' (not *mebuye). Vowel Lowering applies only when the base to which an affix or clitic is attached is nominal or pronominal.

\section{The passive}

Bilabial Palatalisation in the passive can be formulated as a single morphologically conditioned rule:

\section{(31) Passive Palatalisation: $\mathrm{B} \rightarrow \mathrm{J} / \#(\mathrm{X}) \mathrm{CV} \_$(Y) $-w[+$ pass $]$}

A bilabial consonant (cluster) is palatalised before passive $-w$, or before some sequence of phonemes followed by the passive $-w$. The consonant or consonant cluster that changes cannot be the first one in the root or stem.

Furthermore, as Khumalo (1987:171-176) points out, there is no phonological motivation for the palatalisation in examples like $d u b u l+w+a \rightarrow d u t s h u l w a$ ('be shot'), and therefore it can only be a morphologically conditioned rule. Herbert (1977:157) states that "it is not possible to salvage a phonological conditioning in these cases without an otherwise unmotivated appeal to rule ordering" (and by treating sequences like $-u l$ in $d u b u l$ as affixes for which, again, there is no synchronic motivation).

The following table shows sample derivations:

\begin{tabular}{llll} 
(32) & $\begin{array}{l}\text { theng- } \\
\text { 'buy' }\end{array}$ & $\begin{array}{l}\text { khiph } \\
\text { 'take out' }\end{array}$ & $\begin{array}{l}\text { dubul- } \\
\text { 'shoot' }\end{array}$ \\
\hline Affixation & theng-w-a & khiph-w-a & dubul-w-a \\
Passive Palatalisation & - & khish-w-a & dutshul-w-a \\
Glide Formation & - & - & - \\
Labial Glide Dissimilation & - & - & - \\
Y-Deletion & - & - & -
\end{tabular}

Thus the correct form is achieved in a single step. 
Passive Palatalisation must precede Glide Deletion, as shown in (32). If the rules are applied in the opposite order, then the passive morpheme $-w$ would be deleted after bilabials and no palatalisation would take place. This is demonstrated in the following derivation:

\begin{tabular}{ll} 
(33) & $\begin{array}{l}\text { khiph- } \\
\text { 'take out' }\end{array}$ \\
\hline Affixation & khiph-w-a \\
Glide Formation & - \\
Labial Glide Dissimilation & khiph-y-a \\
Y-Deletion & *khiph-a \\
Passive Palatalisation & -
\end{tabular}

\section{The rules required for palatalisation}

The approach described here assumes a strict separation between morphologically conditioned and phonologically conditioned rules. The Zulu Bilabial Palatalisation rules have been shown to be morphologically conditioned because they only operate in certain morphological circumstances and not in others.

The *VV Avoidance rules (see Appendix) have likewise been shown to be morphologically conditioned. The Vowel Lowering rule operates only on nominal bases and not on verbs or predicates; furthermore, it has to be ordered before the morphologically conditioned rule of Locative Palatalisation. The rules of Glide Formation, Y-Deletion and Vowel Deletion have to be ordered before the morphologically conditioned rule of Diminutive Palatalisation.

The following rules are analysed as morphologically conditioned:
a. Vowel Lowering: $\mathrm{V} \rightarrow[-\mathrm{hi}] /\left[\mathrm{V}_{[-\mathrm{hi}} \_\right]$nom
b. Locative Palatalisation: $\mathrm{BV}_{[+\mathrm{bk}]} \rightarrow \mathrm{J} / \ldots$-ini $\sim$-eni $[+\mathrm{loc}]$
c. Passive Palatalisation: $\mathrm{B} \rightarrow \mathrm{J} / \#(\mathrm{X}) \mathrm{CV} \_$(Y) $-w[+$ pass $]$
d. Glide Formation: $\mathrm{V}_{[\{+\mathrm{hi},+\mathrm{bk}\}] \rightarrow[-\mathrm{syl}] /}-\mathrm{V}$
e. Labial Glide Dissimilation: $\mathrm{w} \rightarrow \mathrm{y} /\left\{\mathrm{B} \_, \mathrm{C} \_\mathrm{V}_{[+\mathrm{bk}]}\right\}$
f. Y-Deletion: $\mathrm{y} \rightarrow \varnothing / \mathrm{C}$
g. Vowel Deletion: $\mathrm{V}_{[-\mathrm{hi},-\mathrm{bk}]} \rightarrow \varnothing / \mathrm{V}_{[-\mathrm{hi}]}$
h. Diminutive Palatalisation: $\mathrm{B} \rightarrow \overline{\mathrm{J} /}$ _ - ana $[+\operatorname{dim}]$

Khumalo (1987) proposed the rule of Labial Glide Dissimilation because he believed that Bilabial Palatalisation in the locative could be explained by applying a phonological rule of Labial Palatalisation to sequences of bilabial consonant $+y$. However, as has been shown above, all instances of Bilabial Palatalisation are morphologically conditioned. It is therefore not necessary to have a $w$ dissimilate to $y$ after a bilabial only to be subsequently deleted. Instead, Labial Glide Deletion can simply be replaced by a rule of W-Deletion (35) which achieves the deletion in a single step.

$$
\text { W-Deletion: } \mathrm{w} \rightarrow \varnothing /\left\{\mathrm{B} \_, \mathrm{C} \_\mathrm{V}_{[+\mathrm{bk}]}\right\}
$$

As palatalisation is morphologically conditioned, the question of a phonological trigger does not arise. 
The rules above have all been analysed as phonologically conditioned, most notably by Khumalo (1987). Further arguments against such an analysis follow below.

\section{Khumalo's (1987) phonological account of palatalisation}

\subsection{Khumalo's palatalisation rules}

The pre-eminent advocate of a synchronic phonological treatment of palatalisation is Khumalo (1987). Using the framework of Autosegmental Phonology, Khumalo argues that there are two rules of Labial Palatalisation that operate in Zulu. The first one, which he calls "Labial Palatalisation \#1" (1987:176), operates in the diminutive, the locative, and in passives like khiph-w- $a \rightarrow k h i s h-w$ $a$ ('be taken out'), where the bilabial consonant directly precedes the passive morpheme. According to him, Labial Palatalisation \#1 is phonologically conditioned, "applying wherever its structural description is met" (1987:176). He gives the rule as follows (1987:164):

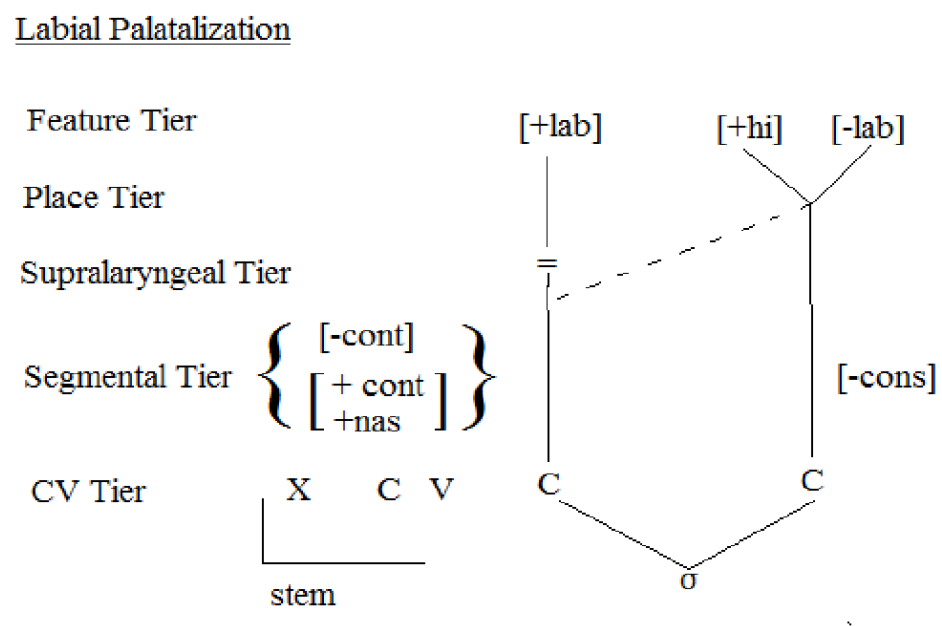

In generative terms, the rule can be formulated, somewhat less elaborately, thus:

$$
\text { Labial Palatalisation \#1: } \mathrm{B} \rightarrow \mathrm{J} /\left[\mathrm{X} \_y\right]_{\text {stem }}
$$

Labial Palatalisation \#1 does not account for the kind of palatalisation seen in passive stems like dubul-w- $a \rightarrow$ dutshul-w- $a$ ('be shot'), where no $y$ appears next to the affected bilabial consonant at any stage of the derivation. Khumalo calls this latter kind of change "Labial Palatalisation \#2" (1987:176) and argues that it is morphologically conditioned because the change cannot be ascribed to $y$-juxtaposition.

Although Labial Palatalisation \#1 is phonologically conditioned according to Khumalo, he claims that in the diminutive and the passive, the juxtaposition of the bilabial consonant and the $y$ is brought about by morphologically conditioned rules.

However, the analysis of Labial Palatalisation \#1 as phonological is incorrect, as the rule itself shows in (36). Khumalo formulates the rule so that it operates only over stems and not in prefixes, thereby ensuring that it only applies to certain morphological forms and not to others. If Labial Palatalisation \#1 were truly a phonological process, it would operate in forms like bu- 
enele ('it (cl.14) is enough'), and umu-elusi ('herdboy'); but, as shown in (18), no palatalisation takes place in such forms.

\subsection{The diminutive}

Khumalo assumes that a morphologically conditioned rule operates in the diminutive in order to create the environment where Labial Palatalisation \#1 operates. Following Stahlke (1976:51), he analyses the diminutive morpheme as -yana rather than - ana, and proposes a morphological rule of Diminutive Delink which elides the final vowel of the noun stem before the diminutive suffix (1987:180). In generative terms, the rule can be formulated as follows:

Diminutive Delink: a vowel is elided before the diminutive suffix -yana.

$$
\mathrm{V} \rightarrow \varnothing / \text {-yana[+dim] }
$$

Thus his derivation of diminutive forms, like those in (25) and (26), would proceed as follows:

\begin{tabular}{|c|c|c|}
\hline $\begin{array}{l}\text { umfula } \\
\text { 'river' }\end{array}$ & $\begin{array}{l}\text { uphaphe } \\
\text { 'feather' }\end{array}$ & $\begin{array}{l}\text { isigubhu } \\
\text { 'calabash' }\end{array}$ \\
\hline $\begin{array}{l}\text { umfula-yana } \\
\text { umful-yana } \\
\text { umful-ana }\end{array}$ & $\begin{array}{l}\text { uphaphe-yana } \\
\text { uphaph-yana } \\
\text { uphash-yana } \\
\text { uphash-ana }\end{array}$ & $\begin{array}{l}\text { isigubhu-yana } \\
\text { isigubh-yana } \\
\text { isiguj-yana } \\
\text { isi-guj-ana }\end{array}$ \\
\hline
\end{tabular}

However, as shown in section 3, Bilabial Palatalisation is a morphological rule, not a phonological one. It is therefore more economical to assume that the diminutive morpheme is - ana, the form it always has on the surface; that the vowel elision is brought about by the independently motivated *VV Avoidance rules of Glide Formation, Glide Elision and Vowel Deletion; and that a morphologically conditioned rule of Diminutive Palatalisation operates after these *VV Avoidance rules. This is the analysis presented in section 4 of this paper.

Kotzé and Zerbian (2008) argue against the analysis of the diminutive suffix as -yana, because in the Sotho languages "[w]ith noun stems ending in the low vowel $<\mathrm{a}>$ no sound changes are observed, except that stem-final $<\mathrm{a}>$ is deleted [...]" (Kotzé and Zerbian 2008:12). Because there is no sound change, the diminutive suffix cannot be -yana. This argument, however, does not apply to Zulu as stems that end in a bilabial followed by $-a$ do undergo palatalisation in the diminutive. Khumalo (1987:181) gives the example of ithuba ('opportunity') $\rightarrow$ ithutshana ('opportunity [dim]'). A stronger argument for Zulu is that, on the surface, the diminutive always has the form -ana. As Diminutive Palatalisation is morphological, the most parsimonious assumption is that the palatalisation is triggered by the diminutive suffix -ana.

\subsection{The locative}

In Khumalo's (1987:134ff) analysis, all the processes that affect the locative are phonological. He postulates a phonological rule of Glide Dissimilation, whereby a $w$ following a bilabial consonant becomes $y$. After that, Labial Palatalisation \#1 applies (see (36) and (37)), palatalising the bilabial.

The table in (40) below gives sample derivations, following Khumalo's (1987) account. 


\begin{tabular}{llll}
$\begin{array}{l}\text { isondo } \\
\text { 'wheel' }\end{array}$ & $\begin{array}{l}\text { indaba } \\
\text { 'affair' }\end{array}$ & $\begin{array}{l}\text { ichibi } \\
\text { 'pool' }\end{array}$ & $\begin{array}{l}\text { izihlobo } \\
\text { 'relatives' }\end{array}$ \\
\hline e-sondo-ini & e-ndaba-ini & e-chibi-ini & e-zihlobo-ini \\
e-sondo-eni & e-ndaba-eni & - & e-zihlobo-eni \\
e-sondw-eni & - & e-chiby-ini & e-zihlobw-eni \\
- & - & - & e-zihloby-eni \\
- & - & e-chitshy-ini & e-zihlotshy-eni \\
- & - & e-chitsh-ini & e-zihlotsh-eni \\
- & e-ndab-eni & - & -
\end{tabular}

Once again, as explained in section 3, Labial Palatalisation \#1 is a morphological rule, not a phonological one. The analysis presented in section 5 reflects this, simply assuming that sequences of $\mathrm{BV}_{[+\mathrm{bk}]}$ are replaced by palatals before the locative suffix $-i n i \sim-e n i$, without invoking any phonological motivation.

Furthermore, Khumalo's account produces some forms that are actually incorrect, because bilabials occur before instances of $y$ that are not derived from $w$. Such bilabials should not undergo palatalisation. This is shown in the derivation of e-chibi-ini in table (40): by Glide Formation, this becomes e-chiby-ini. In Khumalo's account, Labial Palatalisation follows Vowel/Glide Realisation, which is his equivalent of Glide Formation (see, for example, Khumalo 1987:177), so e-chiby-ini should then become $e$-chitshy-ini and then, by Y-Deletion, *e-chitsh-ini. However, the correct locative form of $i$-chibi is $e$-chib-ini with no Bilabial Palatalisation.

\subsection{The passive}

Khumalo (1987:163), following Louw (1976), analyses the Zulu passive morpheme as underlyingly $-i w$. A morphological rule of Passive Delink converts this to $-y w$ after roots of the form (CV)CVC (1987:163). The $y$ serves as a trigger of Labial Palatalisation \#1 and is subsequently elided by the general phonological rule of Y-Deletion.

The present analysis differs from Khumalo's (1987) in treating both Labial Palatalisation \#1 and Labial Palatalisation \#2 as morphologically conditioned, and by combining them into a single rule, (31) - repeated in (34c). This analysis conforms to Kotzé and Zerbian's (2008) arguments that the underlying passive morpheme is not $-i w$ but $-w$.

Khumalo's analysis is somewhat redundant as the palatalisation rules have to operate twice once in the morphology and once in the phonology. While there are instances in language of similar rules operating in both the morphology and the phonology, an account which postulates only one palatalisation is more economical.

Kotzé and Zerbian (2008) argue against the analysis of the underlying passive morpheme as -iw on the following grounds: first, when the form - $i w$ is manifest on the surface, it "does not trigger palatalization" (2008:9). They support this statement with data from Northern Sotho but it is also true of Zulu, as seen in (15). Second, given the "distribution characterization of the two allomorphs", it is "more natural" to posit $-w$ as the underlying form (2008:9). (That is, $-w$ is the most general form - the "Elsewhere" form.) In the Nguni languages, of which Zulu is one, $-i w$ occurs with (V)C-roots, and in the perfect, whereas $-w$ is "Elsewhere". Third, "the $-\mathrm{i}$ - of the long passive allomorph can potentially serve as a trigger for palatalization only in the passive" (Kotzé and Zerbian 2008:9). The vowel $i$ does not have a palatalising effect anywhere else. Finally, the passive morpheme in other Bantu languages is $-w$. 
It has been shown that any phonological motivation proposed in the analysis of the Locative Palatalisation results in incorrect forms, and that the Locative Palatalisation must be analysed as morphological. This is true of the other palatalisations as well. Furthermore, the morphologically motivated analysis is more economical: analysing Diminutive Palatalisation as morphological does away with the abstract -yana form of the diminutive morpheme. The morphological analysis of Passive Palatalisation provides a way of accounting for Khumalo's (1987) Labial Palatalisation \#1 and Labial Palatalisation \#2 without having to postulate two separate processes.

\section{Conclusion}

It is apparent that Bilabial Palatalisation in Zulu does not operate in every phonological circumstance where it could, at least theoretically, be applied. This article demonstrates how morphologically conditioned rules, not phonologically conditioned rules, account for Zulu Bilabial Palatalisation, and shows that the rules of *VV Avoidance are also morphologically conditioned. The assignment of these processes to the morphology now raises the question of what processes, if any, may be described as phonologically conditioned. This question will have to be addressed in future articles.

\section{Appendix: The *VV Avoidance rules}

This appendix gives an account of the rules which prevent violation of the surface phonotactic constraint $* \mathrm{VV}$, and which interact with Bilabial Palatalisation in the diminutive and locative. There is no standard name to describe all the processes involved; here, the rules in question will be termed the "*VV Avoidance rules".

In Zulu phonology, there is a surface phonotactic constraint to the effect that "a sequence of two vowel nuclei is not permitted" (cf. Khumalo 1987:66). The constraint can be summarised as $* \mathrm{VV}$. In the morphology, there are many constructions where a vowel-final morpheme is placed before a vowel-commencing one, thus potentially violating the *VV constraint. In such circumstances, one or the other or both of the two V segments undergo various changes, to be illustrated below. A brief empirical survey of the facts of *VV Avoidance is presented in (41), followed by an outline of Aoki’s (1974) and Khumalo's (1987) rules in (42).

The first two vowels in the formulas in (41), those joined by + , illustrate potential violations of the *VV constraint. The vowel or CV cluster after the arrow represents (abstractly, in the case of the symbols " $\mathrm{V}$ " and "CV") the surface form that is found where this potential violation would otherwise occur. For comparative purposes, forms are also cited where the vowel of the first morpheme does not undergo any process of change because the morpheme is followed by a consonant or is word-final. Combinations not shown below either do not occur or occur only in circumstances where the changes brought about are clearly morphologically conditioned.

$$
\begin{aligned}
& a+\mathrm{V}_{\text {[-hi] }} \rightarrow \mathrm{V}_{\text {[-hi] }} \text {, e.g. } n a+\text { omuhle } \rightarrow \text { nomuhle 'with a/the good person' } \\
& a+i \rightarrow e \text {, e.g. } n a+\text { indoda } \rightarrow \text { nendoda 'with a/the man' } \\
& a+u \rightarrow o \text {, e.g. } n a+\text { umuntu } \rightarrow \text { nomuntu 'with a/the person' } \\
& \text { (cf. } n a+l a b a \rightarrow \text { nalaba 'with these (cl.2)') }
\end{aligned}
$$




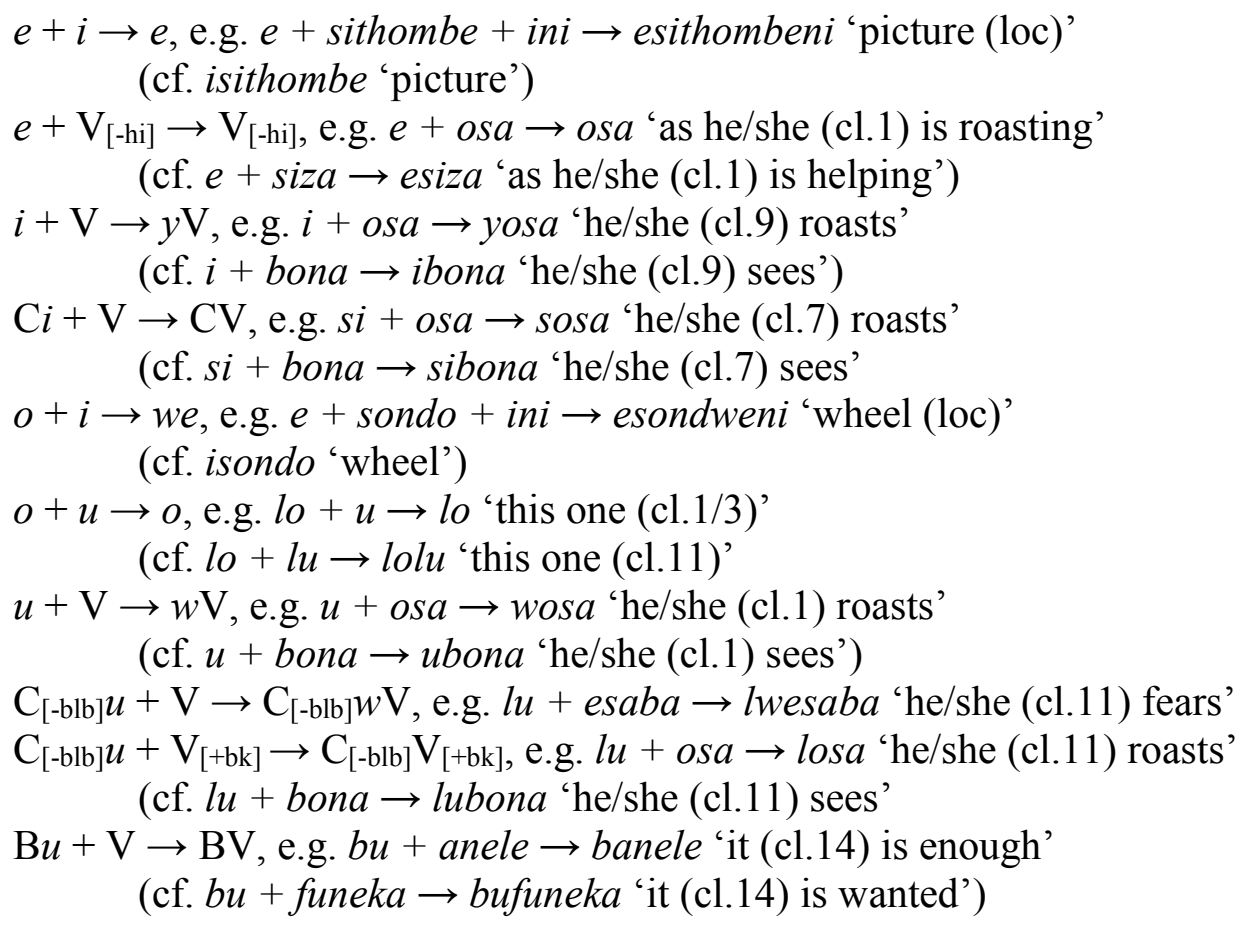

The Aoki-Khumalo analysis of these facts is presented below (Aoki 1974, Khumalo 1987). Except for (b), the names given to the rules are Khumalo's (Aoki (1974) gives the rules numbers rather than names). The rules apply in the order given and account for all the phenomena listed in (42).

(42) a. Vowel Lowering: A high vowel is lowered after a non-high vowel.

$$
\begin{aligned}
& n a+\text { intombi } \rightarrow n a+\text { entombi 'with a girl' } \\
& e+\text { sondo }+i n i \rightarrow e+\text { sondo }+ \text { eni 'on the wheel' }
\end{aligned}
$$

b. Glide Formation: A high or back vowel becomes a glide before another vowel. (Khumalo first has a mid back vowel raise to high by means of a rule he calls "Labial Glide Formation" (1987:142). It then becomes a glide by means of a rule he calls "Vowel/Glide Realisation" but the effect is the same.)

$$
\begin{aligned}
& i+a+\text { ethu } \rightarrow y+a+\text { ethu 'our [cl.9]' } \\
& s i+a+\text { ethu } \rightarrow \text { sy }+a+\text { ethu 'our [cl.7]' } \\
& b u+a+\text { ethu } \rightarrow b w+a+\text { ethu 'our [cl.14]' } \\
& e+\text { sondo }+ \text { eni } \rightarrow e \text {-sondw-eni 'on the wheel' }
\end{aligned}
$$

c. Labial Glide Dissimilation: A labiovelar glide is dissimilated to $y$ after a bilabial consonant or between a consonant and a back vowel.

$$
b w+a+e t h u \rightarrow b y+a+e t h u \text { 'our [cl.14]' }
$$

d. Y-deletion: A palatal glide is elided after a consonant.

$$
\begin{aligned}
& s y+a+e t h u \rightarrow s+a+e t h u \text { 'our [cl.7]' } \\
& b y+a+\text { ethu } \rightarrow b+a+e \text { thu 'our [cl.14]' }
\end{aligned}
$$

e. Vowel Deletion: A vowel is elided before another vowel.

$$
\begin{aligned}
& b+a+e t h u \rightarrow b+e t h u \text { 'our [cl.14]' } \\
& s+a+e t h u \rightarrow s+e t h u \text { 'our [cl.7]' }
\end{aligned}
$$


These rules apply in numerous circumstances in Zulu: in nouns when noun class prefixes are attached to V-commencing stems; in verbs when subject, object or inflectional affixes are attached to V-commencing stems; and when cliticising prepositions (e.g. $n a-$ 'with', $n g a-$ 'by means of', agr- $a$ - 'possessive' - see Du Plessis (1993), Van der Spuy (2006)) are attached to nominals. They also operate when the locative suffix $-i n i$ is attached to a noun (Khumalo 1987:145).

\section{References}

Aoki, P.K. 1974. An observation of vowel contraction in Xhosa. Studies in African Linguistics 5(2): 223-241.

Aronoff, M. 1976. Word formation in generative grammar. Cambridge, MA: MIT Press.

Bloomfield, L. 1935. Language. London: Henderson and Spalding.

Canonici, N.N. 1996. Imisindo yesiZulu: An introduction to Zulu phonology. Durban: University of KwaZulu-Natal.

Chomsky, N. and M. Halle. 1968. The sound pattern of English. New York: Harper and Row.

Doke, C.M. 1926. The phonetics of the Zulu language. Bantu Studies 2. Special Issue.

Doke, C.M. 1927. Textbook of Zulu grammar. (First edition.) Johannesburg: Longmans

Doke, C.M. 1973. Textbook of Zulu grammar. (Sixth edition.) Johannesburg: Longmans.

Du Plessis, J.A. 1993. Inflection in syntax. In P.M.S. Von Staden (ed.) Linguistica Festschrift E.B. van Wyk - 'n Huldeblyk. Pretoria: Van Schaik. pp. 61-66.

Goldsmith, J.A. 1990. Autosegmental and metrical phonology. Oxford: Basil Blackwell.

Guthrie, M. 1971. Comparative Bantu, Volume 2. Farnborough: Gregg.

Halle, M. and A. Marantz. 1993. Distributed Morphology and the pieces of inflection. In K. Hale and S.J. Keyser (eds.) The view from Building 20: Essays in linguistics in honor of Sylvain Bromberger. Cambridge, MA: MIT Press. pp. 111-176.

Herbert, R.K. 1977. Morphophonological palatalization in Southern Bantu: A reply to segmental fusion. Studies in African Linguistics 8(2): 143-171.

Herbert, R.K. 1990. Labial palatalization in Nguni and Sotho languages: Internal and external evidence. South African Journal of African Languages 10(2): 74-80.

Khumalo, J.S.M. 1987. An Autosegmental Account of Zulu Phonology. PhD thesis, University of the Witwatersrand. 
Kiparsky, P. 1982. From cyclic phonology to lexical phonology. In H. van der Hulst and N. Smith (eds.) The structure of phonological representations. Vol. 1. Dordrecht: Foris. pp. 131-175.

Kiparsky, P. 1985. Some consequences of lexical phonology. Phonology Yearbook 2: 83-136.

Kotzé, A.E. and S. Zerbian. 2008. On the trigger of palatalization in the Sotho languages. Journal of African Languages and Linguistics 29(1): 1-28.

Louw, J. 1976. Palatalization of bilabials in the passive, diminutive and locative in Xhosa and Tsonga. Afrika und Übersee: Sprachen, Kulturen 59(4): 241-278.

Malambe, G.B. 2010. A typology of palatalization in Southern Bantu languages. Malilime: Malawian Journal of Linguistics 5: 40-60.

Ohala, J.J. 1978. Southern Bantu vs the world: The case of palatalization of labials. Proceedings of the Berkeley Linguistic Society 4: 370-386.

Poulos, G. and C.T. Msimang. 1998. A linguistic analysis of Zulu. Cape Town: Via Afrika.

Progovac, L. 1993. Non-augmented NPs in Kinande as negative polarity items. In S.A. Mchombo (ed.) Theoretical aspects of Bantu grammar. Stanford: CSLI. pp. 257-269.

Stahlke, H.F.W. 1976. Segment sequences and segmental fusion. Studies in African Linguistics 7(1): 41-63.

Van der Spuy, A. 2006. Wordhood in Zulu. Southern African Linguistics and Applied Language Studies 24(3): 311-329. 